\title{
COMPARISON EFFICACY OF ITS AND 18S rDNA PRIMERS FOR DETECTION OF FUNGAL DIVERSITY IN COMPOST MATERIAL BY PCR-DGGE TECHNIQUE
}

\author{
Pham Ngoc Tu Anh, Pham Thi Thu Hang ${ }^{\bowtie}$, Le Thi Quynh Tram, Nguyen Thanh Minh, Dinh Hoang \\ Dang Khoa
}

Institute for Environment and Resource (IER), Vietnam National University Ho Chi Minh City

To whom correspondence should be addressed. E-mail: thuhangp@gmail.com

Received: 27.11.2017

Accepted: 28.12.2017

SUMMARY

\begin{abstract}
Through composting process, biosolid wastes are gradually transformed into compost material which can be used as soil fertilizer. Among microorganisms involved in composting process, fungi play important roles because they break down complex substrates, such as ligno-cellulose. Recently, PCR-DGGE technique has been considered as a useful tool for analysis of fungal diversity in environmental samples. Among other factors, primer set selection is necessary for successful of the PCR-DGGE analysis. There are several PCR primer sets targeting fungal variable regions of $18 \mathrm{~S}$ ribosomal DNA (rDNA) and internal transcribed spacer (ITS) for the use in community analyses, however there exist just few reports on efficacy of these primers in studying fungal communities in compost materials. In this study, four different primer sets were tested, including EF4/Fung5 (followed by EF4/NS2-GC), EF4/ITS4 (followed by ITS1F-GC/ITS2), NS1/GC-Fung, and FF390/FR1-GC. Extracted DNA from compost materials often contains co-extracted humic substances and other PCR inhibitors. Therefore, the primers were tested for (i) tolerance to the PCR inhibitors presenting in the DNA extracted from compost materials, and (ii) efficacy and specificity of the PCR. The results showed that of the four primer sets, only FF390/FR1-GC achieved both criteria tested whereas the other three did not, i.e. primer EF4/ITS4 had low tolerance to PCR inhibitors, primers EF4/Fung5 was low in PCR amplification efficacy, whereas primers EF4/ITS4 created unspecific products. DGGE analyses of PCR products amplified with the primer set FF390/FR1-GC showed single bands for reference pure cultures Penicillium sp., Aspergillus sp., and Trichoderma sp., as well as distinctly separated bands for the fungal communities of three different composting materials. Thus, the primer set FF390/FR1-GC could be suitable for studying structure and dynamic of fungal communities in compost materials.
\end{abstract}

Keywords: Compost, fungal communities, ITS, PCR-DGGE, primer evaluation, $18 S$ rDNA.

\section{INTRODUCTION}

Composting is an effective method for treatment of municipal solid waste. During composting process, organic matters undergo decomposition by bacteria, fungi and invertebrates. The end product of composting process could be used as a fertilizer for agricultural soil. In composting process, fungi play important roles because they break down complex substrates, such as ligno-cellulose, enabling bacteria to continue the decomposition process. Therefore, understanding of structure and dynamic of fungal community involving in composting process is important for improving the degradation efficacy and compost quality.
The application of molecular techniques such as PCR-DGGE has been proven successful in the investigation of microbial community structure in environmental samples, at the same time enables comparison among many samples (Muyzer et al., 1993). For fungal communities, the $18 \mathrm{~S}$ rDNA and ITS regions have been widely used for PCR-DGGE technique applied to variety of environmental samples (Van Elsas et al., 2000; Kowalchuk et al., 2006). However, it is remained unequivocal about efficacy of primer sets for PCR-DGGE analyses of fungal communities in compost materials (Anderson, Cairney, 2004). The primer sets suitable for this application should be (i) highly tolerant to humic compounds and other PCR inhibitors co-extracted 
from compost during DNA extraction (Tebbe, Vahjen, 1993) and (ii) highly specific, i.e. do not produce products of other sizes than the target DNA fragments.

The present study aims to re-evaluate four previously published fungal specific PCR primer sets targeting $18 \mathrm{~S}$ rDNA and ITS regions for (i) their tolerance to PCR-inhibitory agents in the extracted DNA, and (ii) the amplification efficacy in creating PCR products for the DGGE analyses.

\section{MATERIALS AND METHODS}

\section{Sample collection}

Composting materials were collected at municipal waste composting plant in Binh Duong province. The biosolid waste was dumped in 100 ton piles, supported by active aeration. The compost samples for the study were collected at the surface and $25-\mathrm{cm}$ depth of six different piles from the $10^{\text {th }}, 25^{\text {th }}, 42^{\text {th }}$, and $60^{\text {th }}$ composting day. The samples were quickly transported to laboratory for analyzing. Temperature at each sampling point was recorded with a thermometer.

\section{Extraction of total DNA}

Two gram of composting sample were mixed with $15 \mathrm{~mL}$ phosphate buffer $(0.1 \mathrm{M}, \mathrm{pH} 8,2 \%$ Polyvinylpolypyrrolidone (PVPP)), shaken for 30 min, then spin down at $500 \mathrm{rpm}$ in $1 \mathrm{~min}$. The supernatant was collected, then subsequently centrifuged at $8000 \mathrm{rpm}$ in $5 \mathrm{~min}$, the pellet was then collected for DNA extraction. From this point, DNA extraction was performed according to LaMontagne (LaMontagne et al., 2002) with a modification, in which PVPP was added to the final concentration of $2 \%$ into lysis buffer (150 mM TrisCl pH 8.0, $3 \mathrm{mM}$ EDTA, $1.5 \%$ CTAB, $1 \mathrm{M} \mathrm{NaCl}$ ). Extracted DNA was dissolved in $100 \mu$ l of sterile distilled water.

\section{Primers and Polymerase Chain Reaction (PCR)}

The PCR mixture $(25 \mu \mathrm{L})$ containing approximately $50 \mathrm{ng}$ template DNA, 0.5 U MyTaq, $1 \times$ MyTaq Buffer (Thermo scientific), 20 pmol of each primer. The thermo-cycling was performed using a MyCycler Thermal cycler (Bio-Rad, UK). The thermo cycles for PCR with different primer set were presented in table 1 .

Table 1. Primer sets and PCR conditions used in the study. Size of nested PCR amplicons of primer set number 1 , and number 2 are in parentheses.

\begin{tabular}{|c|c|c|c|c|}
\hline No & Primer sets & $\begin{array}{l}\text { PCR product } \\
\text { length (bp) }\end{array}$ & References & PCR conditions \\
\hline 1 & $\begin{array}{l}\text { EF4/Fung5 } \\
\text { (followed by } \\
\text { EF4/NS2-GC) }\end{array}$ & $600(400)$ & $\begin{array}{l}\text { White et al., 1990/ } \\
\text { Smit et al., } 1999\end{array}$ & $\begin{array}{l}\text { First round: } 95^{\circ} \mathrm{C} / 180 \mathrm{~s} \text {, followed by } 30 \\
\text { cycles of }\left(94^{\circ} \mathrm{C} / 30 \mathrm{~s}, 48^{\circ} \mathrm{C} / 45 \mathrm{~s}, 72^{\circ} \mathrm{C} / 90 \mathrm{~s}\right) \text {, } \\
\text { then } 72^{\circ} \mathrm{C} / 5 \mathrm{~min}\end{array}$ \\
\hline 2 & $\begin{array}{l}\text { EF4/ITS4 } \\
\text { (followed by } \\
\text { ITS1F-GC/ITS2) }\end{array}$ & $1500(290)$ & $\begin{array}{l}\text { White et al., 1990) } \\
\text { Smit et al. } \\
\text { 1999/Gardes, 1993) }\end{array}$ & $\begin{array}{l}\text { First round: } 95^{\circ} \mathrm{C} / 180 \mathrm{~s} \text {, followed by } 40 \\
\text { cycles of }\left(94^{\circ} \mathrm{C} / 30 \mathrm{~s}, 55^{\circ} \mathrm{C} / 30 \mathrm{~s}, 72^{\circ} \mathrm{C} / 60 \mathrm{~s}\right) \text {, } \\
\text { then } 72^{\circ} \mathrm{C} / 5 \mathrm{~min}\end{array}$ \\
\hline 3 & NS1/GC-Fung & 500 & May et al., 2001 & $\begin{array}{l}95^{\circ} \mathrm{C} / 180 \mathrm{~s}, \text { followed by } 30 \text { cycles of } \\
\left(94^{\circ} \mathrm{C} / 15 \mathrm{~s}, 50^{\circ} \mathrm{C} / 30 \mathrm{~s}, 72^{\circ} \mathrm{C} / 30 \mathrm{~s}\right) \text {, then } \\
72^{\circ} \mathrm{C} / 5 \mathrm{~min}\end{array}$ \\
\hline 4 & FF390/FR1-GC & 500 & Vainio, Hantula, 2000 & $\begin{array}{l}95^{\circ} \mathrm{C} / 180 \mathrm{~s} \text {, followed by } 30 \text { cycles of } \\
\left(94^{\circ} \mathrm{C} / 15 \mathrm{~s}, 50^{\circ} \mathrm{C} / 30 \mathrm{~s}, 72^{\circ} \mathrm{C} / 30 \mathrm{~s}\right) \text {, then } \\
72^{\circ} \mathrm{C} / 5 \mathrm{~min}\end{array}$ \\
\hline
\end{tabular}

\section{Tolerance to PCR inhibitors assay}

Different volumes (from $1 \mu \mathrm{L}$ to $5 \mu \mathrm{L}$ ) of DNA samples extracted from composting materials at days $10^{\text {th }}$, and $60^{\text {th }}$ were added into $25 \mu \mathrm{L}$ PCR reaction mixtures to assess tolerance of the four different primer sets to PCR inhibitors presenting in the DNA samples. Humic acid concentration was determined by spectrophotometric analysis at $340 \mathrm{~nm}$. PCR products were then analyzed on $1.2 \%$ agarose gel electrophoresis.

\section{Denaturing gradient gel electrophoresis}

The PCR amplified 18S rDNA/ITS fragments were analyzed by DGGE according to Muyzer et al. (Muyzer et al., 1993) on DCode Universal Mutation Detection System (Bio-Rad, UK). Gel casting conditions were acrylamide $7.5 \%$, size $22 \times 22 \mathrm{~cm}$ and $0.75 \mathrm{~mm}$ thick with denaturant concentration 
ranging from $65 \%$ at the bottom to $30 \%$ at the top of the gel $(100 \%$ denaturant agent was defined as $7 \mathrm{M}$ urea and $40 \%$ deionized formamide). Thirty microliter loading mixture $(15 \mu \mathrm{L}$ PCR product and $15 \mu \mathrm{L} 2 \times$ loading buffer) was loaded on each well. Electrophoresis conditions were $8 \mathrm{~h}, 150 \mathrm{~V}$, and $60^{\circ} \mathrm{C}$. Afterward, the gels were stained with ethidium bromide $0.5 \mathrm{mg} / \mathrm{L}$ for $30 \mathrm{~min}$, rinsed for $10 \mathrm{~min}$ with Mili-Q water, and observed under UV light.

\section{RESULTS AND DISCUSSIONS}

Recently, molecular biological techniques have been proved as useful and reliable tools for investigating of microbes in different environmental samples, including compost material. However, it is known that humic acid contamination in the DNA extracted from environmental samples is the main problem for downstream application of molecular techniques, especially PCR (Miller, 2001). Humic acid in soil and compost samples could be coextracted and interfere with DNA detection because of their physico-chemical similarity with nucleic acid and their inhibition capacity of PCR reaction (Zhou et al., 1996). This contamination can inhibit the activity of Tag DNA polymerase during PCR amplification of targeted gene regions (Luo et al., 2003).

In this study, we used the modified DNA extraction procedure based on CATB according to LaMontagne (LaMontagne et al., 2002) which allowed to obtain high yield of DNA with high integrity and purity for biological molecular PCRbased analysis (Pham Thi Thu Hang et al., 2015).

Table 2. Result of DNA extraction from composting materials. Two gram composting materials of each samples were extracted according to LaMontagne proposed method. Extracted DNA was dissolved in $100 \mu$ l of sterile distilled water.

\begin{tabular}{lll}
\hline Sample & DNA concentration $(\mathbf{n g} / \boldsymbol{\mu l})$ & A260/A280 \\
\hline Compost $10^{\text {th }}$ day & 22.50 & 1.80 \\
Compost $25^{\text {th }}$ day & 182.80 & 1.94 \\
Compost $42^{\text {th }}$ day & 89.33 & 1.91 \\
Compost $60^{\text {th }}$ day & 107.00 & 1.74 \\
\hline
\end{tabular}

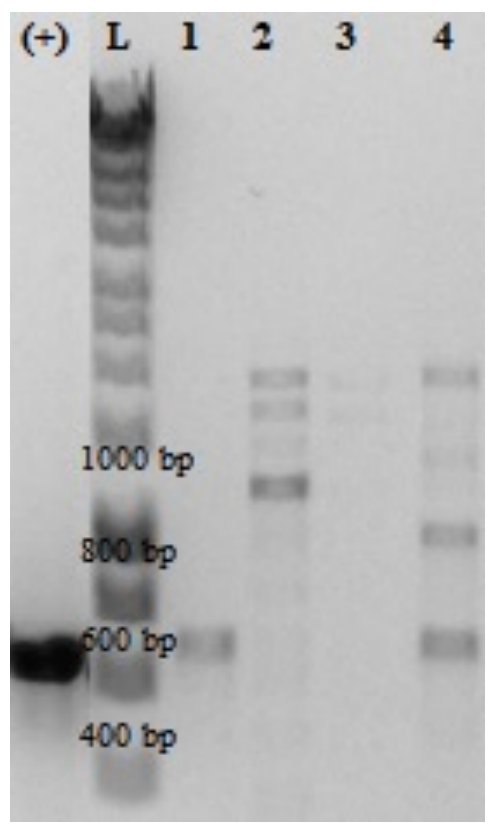

A

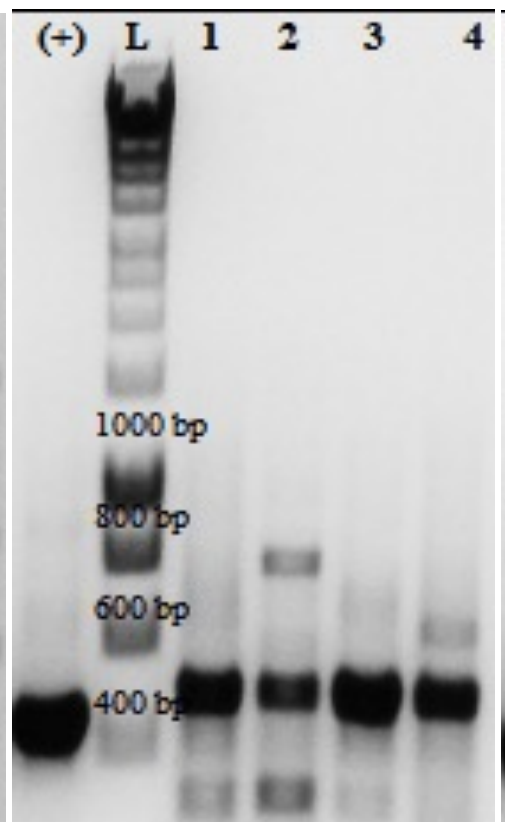

B

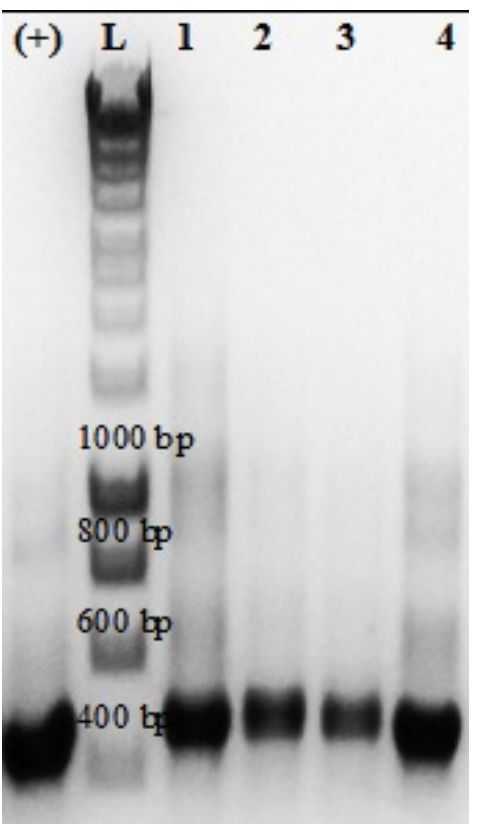

C

Figure 1. Electrophoresis of PCR products of three primer sets (A) EF4/Fung5, (B) NS1/GC-Fung, and (C) FF390/FR1-GC. In each gel, from left to right are PCR products of a specific primer set with different DNA templates including DNA from Aspergillus sp. $(+)$ as a positive control, and four DNA samples from composting materials at day $10^{\text {th }}, 25^{\text {th }}, 42^{\text {th }}$, and $60^{\text {th }}$ (lane 1 to 4 ). 
It has been reported that humic acid level in biosolid material is increasing during composting process, therefore two extracted DNA from composting material at early-phase $\left(10^{\text {th }}\right.$ day $)$ and at end-phase $\left(60^{\text {th }}\right.$ day) were used to determined the tolerance capacity against humic acid and other PCR inhibitors of the four primer sets. The concentration of humic acid in the two extracted DNA samples from $10^{\text {th }}$, and $60^{\text {th }}$ day compost materials were 0.4 $\mathrm{ng} / \mu \mathrm{L}$ and $4.5 \mathrm{ng} / \mu \mathrm{L}$, respectively. The level of coextracted PCR inhibitors was gradually increased by increasing the total added volume of the extracted DNA solution into the PCR reaction mixtures. The results showed that except primer set EF4/ITS4, all of three others have created PCR products with DNA extracted from the $10^{\text {th }}$ day compost material added at volumes in range $1 \mu \mathrm{L}$ to $5 \mu \mathrm{L}$ (Fig. 1). The primer set FF390/FR1-GC showed best tolerance capacity toward PCR inhibitors, created PCR products even when $2 \mu \mathrm{L}$ of DNA extracted from the $60^{\text {th }}$ day compost material was added in total $25 \mu \mathrm{L}$ PCR reaction mixture (Fig.1C). The primer set EF4/ITS4 was fail in amplifying PCR products with any DNA template extracted from compost samples, but could amplify DNA from a pure-culture of Aspergillus sp. Moreover, EF4/ITS4 targeted sequence was $1500 \mathrm{bp}$ in length, the result suggested that PCR inhibitory effects of co-extracted inhibitors from compost material might be magnified with the length of targeted sequence.

Table 3. Tolerance of different primers to inhibitory effects of humic acid and other PCR inhibitors existed in total DNA extract from composting materials. DNA sample from cultured Aspergillus sp. was used as positive control. The symbol (+)/(-) refers successful/not successful of a PCR reaction.

\begin{tabular}{|c|c|c|c|c|c|c|c|c|c|c|c|c|c|}
\hline \multirow{2}{*}{ Order } & \multirow{2}{*}{ Primer sets } & \multirow{2}{*}{ Length (bp) } & \multirow{2}{*}{ Aspergillus sp. } & \multicolumn{5}{|c|}{ Compost $10^{\text {th }}$ day $(\mu \mathrm{I})$} & \multicolumn{5}{|c|}{ Compost $60^{\text {th }}$ day $(\mu \mathrm{l})$} \\
\hline & & & & 1 & 2 & 3 & 4 & 5 & 1 & 2 & 3 & 4 & 5 \\
\hline 1 & EF4/Fung5 & 500 & + & + & + & + & + & + & + & - & - & - & - \\
\hline 2 & EF4/ITS4 & 1500 & + & - & - & - & - & - & - & - & - & - & - \\
\hline 3 & NS1/GC-Fung & 350 & + & + & + & + & + & + & + & - & - & - & - \\
\hline 4 & FF390/FR1-GC & 350 & + & + & + & + & + & + & + & + & - & - & - \\
\hline
\end{tabular}

Four extracted DNA samples from materials collected from composting piles at day $10^{\text {th }}, 25^{\text {th }}$, $42^{\text {th }}$, and $60^{\text {th }}$ were used for testing the PCR amplification efficacy of three primer sets EF4/Fung5, NS1/GC-Fung, and FF390/FR1-GC. The primer set EF4/Fung5 created PCR products with DNA extracted from 3 compost samples, at day $10^{\text {th }}, 25^{\text {th }}$, and $60^{\text {th }}$, except DNA from the $42^{\text {th }}$ day, however the amplified products were not strong and varied in length (Figure 1A). The result indicated that the primer set EF4/Fung5 might below in amplification efficacy, and specificity. Both primer set NS1/GC-Fung and FF390/FR1-GC showed high amplification efficacy, the PCR products from all four extracted DNA samples had strong signals at the expected size (Figure 1B,C). Comparing the specificity, primer set FF390/FR1-GC was better than primer set NS1/GC-Fung which created some unspecific PCR products with DNA samples extracted from compost materials at day $10^{\text {th }}, 25^{\text {th }}$, and $60^{\text {th }}$. Of the four primer sets evaluated, the primer set FF390/FR1-GC showed high PCR inhibitors tolerance capacity, high amplification efficacy and specificity, therefore was selected for performing DGGE analyses in the next step.
Three DNA samples from fungal pure cultures including Penicillium sp., Aspergillus sp., Trichoderma $\mathrm{sp}$., and three compost DNA samples at day $10^{\text {th }}, 25^{\text {th }}, 42^{\text {th }}$ were used as templates for PCRDGGE analyses with primer set FF390/FR1-GC. On the DGGE gels, each fungal pure culture showed one clear band (Fig 2-A), while many sharp, well separated bands were observed in DGGE profiles of all the three compost samples (Fig 2B). Number of DGGE bands was gradually decreased from the $10^{\text {th }}$ day sample ( 7 bands) to the $25^{\text {th }}$ ( 6 bands) and the $42^{\text {th }}$ day (4 bands), reflecting higher fungal diversity in compost material at the early day in comparison to the later day of composting process. Obviously, the sample at $10^{\text {th }}$ day had some distinct DGGE bands that were not observed in the other two samples (Figure 2B). Higher fungal diversity in the compost sample at day $10^{\text {th }}$ might be due to more biologically feasible conditions at this stage (such as mesophilic temperatute, high humidity, high concentration of organic carbon) in comparison to more extreme conditions at later stages (high temperature, low humidity, lower organic carbon conent). The observation in this study was in consistence with previous reports, showing that fungi were more 
dominant in early mesophile phase, and lower in thermophile phase of composting process (Dehghani et al., 2012).

Ribosomal RNA genes, especially the small subunit ribosomal RNA genes, i.e., 18S rRNA genes in the case of eukaryotes, have been predominant target for the assessment of microbial community. The primer set FF390/FR1-GC targets two variable regions V8 and V9 of fungal 18S rDNA which have high discrimination capacity of different fungal species (Kowalchuk et al., 2006). The result of this study is in agreement with previous study that primer set FF390/FR1 has high amplification efficiencies, applicable for analysing a wide range of different ascomycetous and basidiomycetous taxa (Vainio, Hantula, 2000). Moreover, the primer can detect high fungal diversity, maintaining specificity for fungi (Hoshino, Morimoto, 2010). Results of this study have indicated that there exist many factors of considertion when evaluating primers to use for PCR-DGGE analysis of fungal communities in complex environmental samples such as compost. In order to better examine the usefulness of the primer set FF390/FR1-GC for investigating fungal diversity of composting process, the DGGE bands of compost samples should be examined at sequence level.

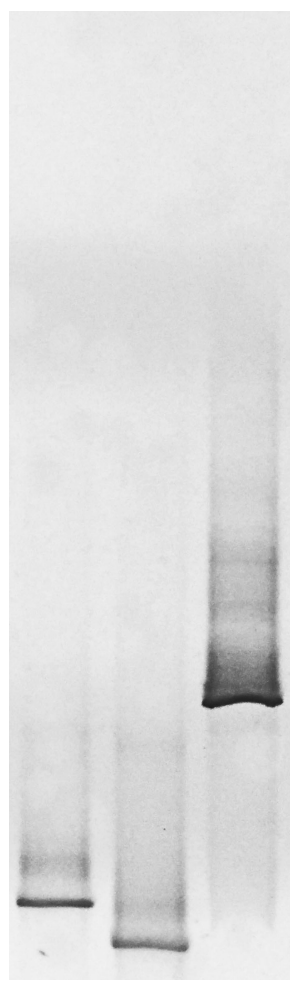

A

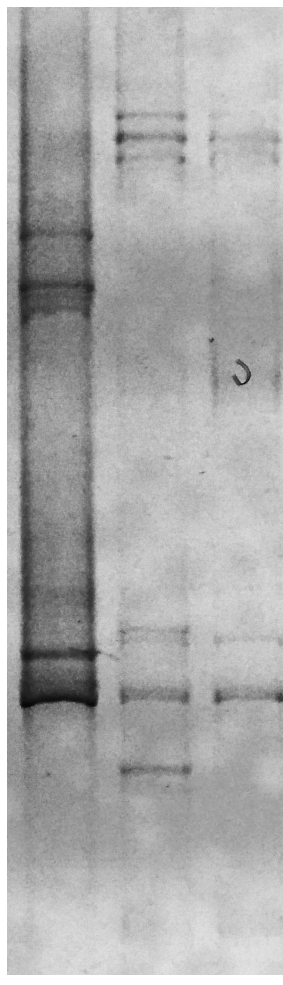

B

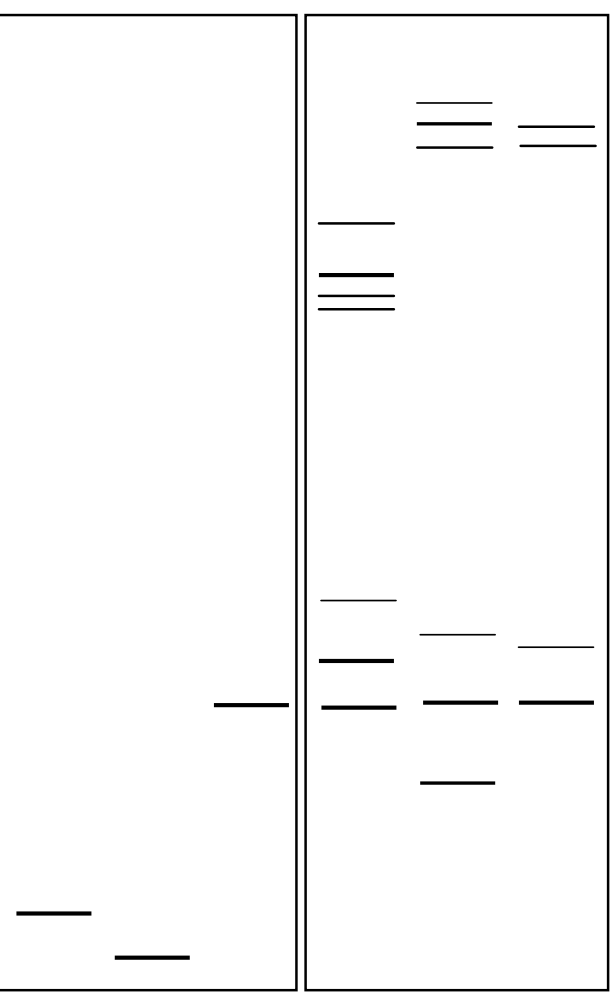

C
D

Figure 2. DGGE profiles of PCR products created by using primer set FF390/FR1-GC (A) From left to right, DGGE profiles of three pure-cultures Penicillium sp., Aspergillus sp., and Trichoderma sp., and (B) DGGE profiles of three total extracted DNA from composting material at day $10^{\text {th }}, 25^{\text {th }}$, and $42^{\text {th }}$. For easier observation, DGGE profiles of pure-culture fungi (A) and compost samples (B) were schematically illustrated at the same positions on (C), and (D), respectively.

\section{CONCLUSION}

Taken together, the experimental data of this study showed that primer set FF390/FR1-GC appeared to have high tolerance to PCR inhibitors co-extrated with
DNA from compost samples, high amplification efficacy and specificity toward V8-V9 regions of fungal $18 \mathrm{~S}$ rDNA. Therefore, the primer set was suggested for the use in investigating fungal diversity in municipal composting process via PCR - DGGE technique. 
Acknowledgments: This research is funded by Vietnam National University of Ho Chi Minh City (VNU-HCM) under grant number C2016-24-04/HĐKHCN was acknowledged. We would like to thank South Binh Duong Solid Waste Treatment Complex for supporting to collect compost samples.

\section{REFERENCES}

Anderson IC, Cairney JWG (2004) Diversity and ecology of soil fungal communities: increased understanding through the application of molecular techniques. Environ Microbiol 6(8): 769-779.

Dehghani R, Asadi MA, Charkhloo E, Mostafaie G, Saffari M, Mousavi GA, Pourbabaei, M (2012) Identification of fungal communities in producing compost by windrow method. J Environ Prot (Irvine, Calif) 3: 61-67.

van Elsas JD, Duarte GF, Keijzer-Wolters A, Smit E (2000) Analysis of the dynamics of fungal communities in soil via fungal-specfic PCR of soil DNA followed by denaturing gradient gel electrophoresis. $J$ Microbiol Methods 43: 133-151.

Kowalchuk GA, Drigo B, Yergeau E \& van Veen JA (2006) Assessing bacterial and fungal community structure in soil using ribosomal RNA and other structural gene markers. Nucleic Acids and Proteins in Soil, Nannipieri P \& Smalla K (Eds): 159-188. Springer Berlin Heidelberg, ISBN 978-3-540-29448-1, Germany.

LaMontagne MG, Michel JrFC, Holden PA, Reddy CA (2002)Evaluation of extraction and purification methods for obtaining PCR-amplifiable DNA from compost for microbial community analysis. J Microbiol Methods 49(3): 255-264.

Luo H, Qi H, Xue K, Zhang H(2003) A preliminary application of PCR-DGGE to study microbial diversity in soil. Acta Ecologica Sinica 23(8):1570-1575.

Gardes M, BrunsTD (1993) ITS primers with enhanced specificty for basidiomycetes - application to the identification of mycorrhizae and rusts. Mol Ecol 2: 113-118.

May LA, Smiley B, Schmidt MG (2001) Comparative denaturing gradient gel electrophoresis analysis of fungal communities associated with whole plant corn silage. Can J Microbiol 47(9): 829-841.

Miller DN (2001) Evaluation of gel filtration resins for the removal of PCR-inhibitory substances from soils and sediments. J Microbiol Methods 44(1): 49-58.

Muyzer G, De Waal EC, Uitterlinden A (1993) Profiling of complex microbial populations by denaturing gradient gel electrophoresis analysis of polymerase chain reactionamplified genes coding for 16S rRNA. Appl Environ Microbiol 59(3): 695-700.

Pham Thi Thu Hang, Dinh Hoang Dang Khoa, Khuat Hoai Phuong, Pham Thi Ngoc Han, Phan The Huy, Nguyen Thi My Dieu (2015) Simple DNA extraction method from compost samples for molecular biological analysis using PCR reactions. Journal of Science and Technology 53(5B).

Smit E, Leeflang P, Glandorf B, Dirk FAN, Wernars K (1999) Analysis of fungal diversity in the wheat rhizosphere by sequencing of cloned PCR-amplied genesencoding $18 \mathrm{~S}$ rRNA and temperature gradient gel electrophoresis. Appl Environ Microbiol 65(6): 2614-2621.

Takada Hoshino Y, Morimoto S (2010) Soil clone library analyses to evaluate specificity and selectivity of PCR primers targeting fungal 18S rDNA for denaturinggradient gel electrophoresis (DGGE). Microbes Environ 25(4): 281-287.

Tebbe CC, Vahjen W (1993) Interference of humic acids and DNA extracted directly from soil in detection and transformation of recombinant DNA from bacteria and a yeast. Appl Environ Microbiol 59(8): 2657-2665.

Vainio E J, Hantula J (2000) Direct analysis of woodinhabiting fungi using denaturing gradient gel electrophoresis of amplified ribosomal DNA. Mycol Res 104: 927-936.

White TJ, Bruns T, Lee S, Taylor J (1990) Amplification and direct sequencing of fungal ribosomal RNA genes for phylogenetics. In Innis MA, Gelfand DH, Sninsky JJ, White TJ, eds. PCR Protocols: A Guide to Methods and Applications. Academic Press, London: 315-322.

Zhou J, Bruns MA, Tiedje JM (1996) DNA recovery from soils of diverse composition. Appl Environ Microbiol 62(2): 316-322. 


\title{
SO SÁNH HIỆU QUẢ CỦA CÁC CẶP MỒI KHUÊCH ĐẠI VÙNG ITS VÀ 18S rDNA CHO VIỆC XÁC ĐỊ̂NH SỬ ĐA DẠNG CỦA VI NẤM TRONG VẬT LIỆU COMPOST BẰNG KỸ THUẠT PCR-DGGE
}

\author{
Phạm Ngọc Tú Anh, Phạm Thị Thu Hằng, Lê Thị Quỳnh Trâm, Nguyễn Thanh Minh, Đinh Hoàng \\ Đăng Khoa
}

Viện Môi trừ̀ng và Tài nguyên, Đại học Quốc gia Thành phố Hồ Chí Minh

\section{TÓM TẮT}

Kỹ thuật PCR-DGGE đã được ứng dụng trong việc phân tích sự đa dạng vi nấm trong nhiều mẫu môi trường. Các cặp mồi sử dụng phổ biến nhất dùng để khuếch đại các vùng biến động của $18 \mathrm{~S}$ rDNA và vùng ITS. Tuy nhiên, chỉ có một vài báo báo về hiệu quả của các cặp mồi này trong việc khuếch đại vùng $18 \mathrm{~S}$ rDNA/ITS của các mẫu DNA được tách chiết từ các vật liệu compost. Trong nghiên cứu này, bốn cặp mồi được sử dụng bao gồm (EF4/Fung5, EF4/NS2-GC); (EF4/ITS4, ITS1F-GC/ITS2); NS1/GC-Fung và FF390/FR1-GC. DNA tổng số được tách chiết từ các vật liệu compost thường sẽ bị lẫn tạp acid humic và các chất ức chế phản ứng PCR, điều này gây trở ngại cho các phân tích sinh học phân tử có sử dụng phản ứng PCR sau đó. Do đó, đầu tiên các cặp mồi được kiểm tra khả năng chống chịu với các chất ức chế có trong mẫu DNA tách từ vật liệu compost, bằng cách lần lượt gia tăng thể tích mẫu DNA vào hỗn hợp phản ứng PCR và quan sát sản phẩm khuếch đại trên gel agarose. Sau đó, hiệu quả khuếch đại và độ đặc hiệu của các cặp mồi đối với mẫu DNA tổng số được tách chiết từ các vật liệu compost cũng được kiểm tra. Các kết quả thí nghiệm cho thấy cặp mồi EF4/ITS4 có khả năng chịu đựng các chất ức chế kém, cặp mồi EF4/Fung5 có hiệu quả khuếch đại thấp, cặp mồi EF4/ITS4 tạo các sản phẩm không đặc hiệu và chỉ có cặp mồi FF390/FR1-GC đáp ứng được các yêu cầu về khả năng chống chịu chất ức chế, hiệu quả khuếch đại, và tính đặc hiệu. Kết quả chạy điện di DGGE các sản phẩm PCR được khuếch đại bằng cặp mồi FF390/FR1-GC cho thấy vạch đơn đối với DNA của các mẫu vi nấm thuần (Penicillium $s p$., Aspergillus sp., và Trichoderma $s p$. .), và các vạch phân tách rõ của DNA tổng số được tách chiết từ ba mẫu compost khác nhau. Kết quả nghiên cứu này cho thấy cặp mồi FF390/FR1-GC là cặp mồi thích hợp cho các nghiên cứu về đa dạng vi nấm trong compost bằng kỹ thuật PCRDGGE. Kết quả của nghiên cứu này có thể phục vụ như tài liệu tham khảo hữu ích cho việc chọn lựa cặp mồi thích hợp để tiến hành các nghiên cứu sâu hơn về sự đa dạng và cấu trúc của cộng đồng vi nấm trong quá trình ủ compost, và sự thay đổi của cộng đồng vi nấm theo thời gian và các điều kiện môi trường khác nhau với kỹ thuật PCR-DGGE.

Từ khóa: Compost, cộng đồng vi nấm, ITS, PCR-DGGE, đánh giá cặp mồi, $18 S$ rDNA. 